\begin{tabular}{|l|l|l|}
\hline \multicolumn{2}{|c|}{ PublisherInfo } \\
\hline \hline PublisherName & $:$ & BioMed Central \\
\hline \hline PublisherLocation & $:$ & London \\
\hline \hline PublisherImprintName & $:$ & BioMed Central \\
\hline \hline
\end{tabular}

\title{
Tamoxifen-resistant breast carcinoma xenograft
}

\begin{tabular}{|l|l|l||}
\hline \multicolumn{2}{|c|}{ ArticleInfo } \\
\hline \hline ArticleID & $:$ & 3716 \\
\hline \hline ArticleDOI & $:$ & $10.1186 /$ bcr-2000-66679 \\
\hline \hline ArticleCitationID & $:$ & 66679 \\
\hline \hline ArticleSequenceNumber & $:$ & 82 \\
\hline \hline ArticleCategory & $:$ & Paper Report \\
\hline \hline ArticleFirstPage & $:$ & 1 \\
\hline \hline ArticleLastPage & $:$ & 4 \\
\hline \hline & & RegistrationDate : 2000-5-25 \\
\hline ArticleHistory & $:$ & OnlineDate \\
\hline \hline ArticleCopyright & $:$ & Current Science Ltd2000-5-25 \\
\hline \hline ArticleGrants & $:$ & \\
\hline \hline ArticleContext & $:$ & 1305822 \\
\hline \hline
\end{tabular}


Valerie Speirs, ${ }^{\text {Aff1 }}$

Aff1 Molecular Medicine Unit, University of Leeds, UK

\section{Keywords}

Breast cancer, cathepsin D, oestrogen receptor, pS2, tamoxifen resistance, xenograft

\section{Introduction}

At diagnosis, approximately $60 \%$ of breast tumours express oestrogen receptor (ER) and are considered hormone-responsive. The current first choice endocrine therapy is the antioestrogen tamoxifen (TAM); however, around one third of breast tumours do not respond to this treatment. Of those that do respond, development of TAM resistance can occur after continued treatment. Most studies examining the development of antioestrogen resistance have used cell lines that have been made resistant by continuous culture in the presence of antioestrogens. These have certain limitations, however; they are not representative of the internal microenvironment of a tumour in vivo and may select for specific subpopulations. As an alternative model, development of a xenograft of a human TAM-resistant mammary tumour, MaCa 3366/TAM, is described.

\section{Aims}

To develop a TAM-resistant subline of an originally sensitive breast cancer xenograft (3366) by longterm treatment of tumour-bearing nude mice with antioestrogen.

\section{Comments}

The development of antioestrogen resistance in breast cancer is a considerable clinical problem. Mechanisms associated with a resistant phenotype have mainly been addressed by the development of resistant cell lines in vitro, but these have some drawbacks as the tissue architecture seen in vitro is lost when cells are placed in culture. Here, a tamoxifen-resistant breast cancer xenograft has been developed and some initial characterisation performed. Because this retains many of the features seen in breast tumours in situ, this is a more clinically relevant model to study antioestrogen resistance. Further studies 
using this model to address some of the mechanisms associated with antioestrogen resistance are keenly awaited.

\section{Methods}

Xenografts of the TAM-sensitive 3366 breast cancer cell line were established in the flanks of NMRI$\mathrm{nu} / \mathrm{nu}$ female mice. Mice received increasing doses of TAM $(1-50 \mathrm{mg} / \mathrm{kg})$ over a 3 year period until the development of TAM resistance. Thereafter they were treated regularly with $50 \mathrm{mg} / \mathrm{kg}$ TAM during passage. For histological investigation, standard procedures were employed. ER and progesterone receptor content of xenografts was determined by commercial immunoassay and the expression of ERregulated genes was by northern blot analysis. Finally, the hormone binding domain of ER was analysed by sequence analysis to look for mutations associated with TAM resistance.

\section{Results}

Histological examination of the TAM-sensitive 3366 xenograft showed a solid ductal invasive

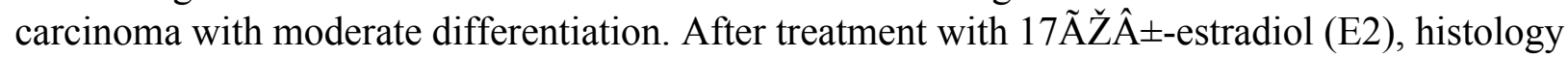
changed to reveal a ductal pattern of growth. These more differentiated structures were not seen in the resistant subline after E2 treatment.In comparison to the parental TAM-sensitive xenograft, TAM failed to induce growth inhibition in the resistant xenograft. Similar inhibition was seen with the pure antioestrogen ICI 182780, indicating cross-resistance.Both sensitive and resistant tumours expressed similar levels of ER $\alpha, E R \beta$ and progesterone receptor. In the sensitive xenografts, ER $\alpha$ was upregulated following E2 treatment, and upregulation of progesterone receptor was also observed. The ER-regulated genes pS2 and cathepsin D were regulated by E2/antioestrogen in the sensitive 3366 tumours, but this was lost in the 3366/TAM cells. Sequence analysis of the ER ligand-binding domain showed no differences between the sensitive and resistant cells.

\section{Discussion}

An in vivo model of TAM resistance has been developed by long-term treatment of nude mice bearing xenografts of the cell line 3366. This model has been characterised in comparison with the TAMsensitive parental cell line and has applicability as a more clinically relevant model to study antioestrogen resistance. 


\section{References}

1. Naundorf H, Becker M, Lykkesfeldt AE, Elbe B, Neumann C, Buttner B, Fichtner I: Development and characterisation of a tamoxifen-resistant breast carcinoma xenograft. Br J Cancer. 2000, 82:

1844-1850.

This PDF file was created after publication. 